\title{
Docencia, decencia y poesía
}

Raquel Romero

Alguien bastante sensato no hace demasiado tiempo me dijo que equilibrar la figura cuando se habla de un homenajeado es cosa difícil. Cierto: difícil, extremadamente difícil. Hay que encontrar el tono, hay que buscar el equilibrio, no debes parecer demasiado entregada a la causa, pero tampoco puedes distanciarte tanto que acabes diseccionando al personaje; y si has perdido el hábito de escribir o tus escritos habituales se reducen a aburridos informes administrativos la cosa se complica aún mucho más. El asunto es que este discurso debería ser el retrato de alguien que ha sido y sigue siendo, para mí y a mi manera, una figura de referencia, alguien verdaderamente importante en mi vida, y sospecho que no hacer de la temida página/pantalla en blanco una especie de cajón de-sastre es un enorme desafío del que, por respeto a Pere Rovira, intentaré salir airosa.

Pere Rovira es un buen maestro y es, además, un maestro bueno. Maestro en sentido primero y original, aunque también en sentido familiar: es un modelo, su ejemplo - permítanme decirlo aunque suene cursi- es único, porque lejos de limitarse a impartir clases ha enseñado a leer, cosa que podría parecer sencilla pero que no le es en absoluto. Su tarea ha consistido, y sigue consistiendo, en mostrar que sí se puede y que se debe mirar el texto, el que sea, más que como un producto del artista, como la seña de identidad de un hombre. Un trabajo difícil, muy difícil, y con un componente de implicación personal y de compromiso por y con la docencia, la paciencia, la decencia y la poesía.

En estas líneas quiero únicamente hablar por mí, aunque he de decir que soy una más de entre los privilegiados que han sido sus alumnos primero y sus lectores después o al mismo tiempo. Y no hay problema en reconocer que quizá alguno que otro esté de acuerdo conmigo, otros no. Ni siquiera hay problema en suponer que algunos de entre esos otros piensen que ellos nunca conocieron al Pere Rovira que intento retratar. No importa. Son mis recuerdos y mis agradecimientos, no los suyos. 
Quiero, desde lo poco o lo mucho que yo he podido conocer de la carrera de Pere Rovira, y por lo que su figura ha representado en la mía a lo largo de los años, agradecer públicamente que me enseñara a leer, a mirar el texto con otros ojos y a entender las redes que teje la buena literatura, a desconfiar de los grandes nombres y a centrar la mirada en aquello que es realmente importante: las palabras. Lástima que no aprendiera de Pere el oficio de escritora.

Recuerdo la antigua sede de la facultad de letras en la Calle Caballeros; las aulas grandes, pequeñas, oscuras, incómodas; los pasillos, las escaleras, el café lleno de humo, pero sobre todo recuerdo la emoción de descubrir que más allá de los discursos, casi sermones de muchos profesores, y de los libros de obligada lectura había otros mundos por visitar, y recuerdo el símbolo que era Pere Rovira y cómo se hablaba de él y recuerdo también a muchos de los que hablábamos de él; muchos que hoy firmamos, en este mismo volumen, escritos de homenaje como el que intento escribir desde hace días.

Pero este no es el camino. Pere Rovira no encaja en un discurso como este, es complejo explicarlo pero estoy convencida de que así es. Sé que cuando lea estas líneas, si es que llega hasta este punto sin bostezar, pensará si no aprendí nada en sus clases, y si después no fui capaz por mí misma de entender que lo importante no es solo lo que dices, también cómo lo dices y muy especialmente cómo suena y si, además, resuena en tu cabeza. Definitivamente se impone un nuevo principio.

Nuevo principio: Pere Rovira fue mucho más que un profesor y lo fue para, al menos, un grupo de estudiantes de literatura jóvenes, muy jóvenes, y entusiastas, seguramente entusiastas en exceso. Los que quisimos escucharle aprendimos de él que la única historia posible de la literatura, de la Literatura en mayúsculas, se construye sin concesiones y sin demasiadas ataduras, con poco o ningún sentido del apego al escritor o a la época o al estudioso de turno, pero con un estricto, ético y estético sentido de la lealtad al texto. Y en el principio, como muestra, estuvo García Márquez con un coronel, un gallo y una carta que nunca llegó y con la familia Buendía, condenada a no tener una segunda oportunidad sobre la tierra. Más tarde llegó la poesía clásica, moderna, antigua, romántica, canalla, trágica, irónica, y su lectura en voz alta: ritmo, rima, tono, cadencia, todo al servicio del lector que es quien pone la voz y arriesga con la intención o con la recepción o con la modernidad de su mirada o con aquello que sea que hace un lector con el texto que realmente lee.

Y este, quizá, tampoco sea el camino.

Otro principio. Allá por los ochenta, cuando conocí a Pere, la política y la ética parecía que habían dejado paso a la estética, y en la facultad andábamos todos buscando cosas importantes y hasta trascendentes que hacer: un ligue, un buen disco, un porro, un libro nuevo, una buena charla, algo que cambiara nuestra percepción, en cierto modo virgen, del mundo en el que vivíamos. Pere Rovira un día, sin que ahora recuerde yo a santo de qué, nos dijo: "Sois hijos de la burguesía, lo que no debería ser un problema" y se apagaron las luces: no entendí nada. Pensé si no habría otra forma, menos directa, más paternal quizá, de decirnos que éramos aún jóvenes y demasiado inocentes, o privilegiados o algo estúpidos o quién sabe qué. Y nos preguntamos, al menos yo me pre- 
gunté muchas veces y mucho tiempo, por qué ser hijo de la burguesía no debería ser un problema, ¿Éramos realmente hijos de la burguesía? Y si lo éramos: ¿por qué ser lo que se es puede ser un problema? ¿Cuál era en realidad el problema? ¿Qué quería decir(me) Pere? No lo supe hasta mucho tiempo después. Como casi siempre él seguía hablándonos de vida, de caza, de conocimiento, de poesía, de nuestras clases, de algunos libros, de cosas importantes a las que un día tras otro, estoy segura, ha seguido llamado por su nombre de pila, fiel al otro gran maestro que admira, Juan de Mairena. Y mientras, yo continuaba preguntándome a qué venía aquella frase que me parecía una terrible, excesiva e injusta acusación.

A Pere le importaba, y seguro que le sigue importando, un rábano lo que al mundo, a mí o al lucero del alba le pareciera lo que él quería decir en sus clases o con frases contundentes como las que pronunciaba y pronuncia sin inmutarse, como quien hace la lista de la compra o redacta una nota para pegar en la nevera; lo que realmente le importaba, y le sigue importando sin ninguna concesión, es hacer pensar, hacer leer y, por extensión, hacer entender. Y me malicio que ha sido esta tarea de maestro la que le ha hecho ser, a lo largo de sus años de docencia y de poeta, el hombre que ha sido. Que nuestras jóvenes cabecitas fueran capaces o no de procesar la verdadera intención de sus provocaciones era misión casi imposible, ahora bien, el objetivo, hacer pensar para luego poder decir, ese se alcanzó.

No hace mucho, en la presentación de una de sus últimas obras, Pere dijo, al referirse a las grandes crisis de nuestra historia cotidiana que, efectivamente, hay dos clases de personas: las vencedoras y las vencidas, pero que la mayor parte de quien sobrevive a cualquiera de las grandes tragedias de la humanidad, y se refería a la dureza de la guerra o a las dificultades económicas de los últimos años, son los vencidos. Los vencidos no pertenecen a ningún bando, ni siquiera a una banda, son solamente seres derrotados que dejan en el camino mucho más de lo que imaginan. En otro momento de esa misma presentación habló de la indecencia y de la soberbia de los poderosos y de la necesidad de combatirlos: ser beligerantes, levantar la voz y resistir pero no con gestos, ni siquiera con ideas, sino con hechos. Habló de dignidad y de principios, pero sobre todo habló de los (y seguramente por los) vencidos. También habló de filosofía y de literatura.

Es el mismo Pere Rovira que me hablaba de no ser condescendiente con los míos - o con los que podrían serlo- desde detrás de su pipa. Para quien tiene que, o quiere, despertar mentes, la paciencia es fundamental, como lo es la decencia. Es necesario, lo dice el maestro, comprender, saber quiénes somos y ser capaz de decirlo y de decirlo bien, no importa cuánto tiempo tengas que dedicarle. No es importante lo que haces, lo que cuenta es cómo lo haces y hasta dónde eres capaz de implicarte con lo que haces y un dia - dice Pere- comprendes que eres como eres, amas a quien amas y vives donde vives, por haberte dedicado a la poesía. ${ }^{1}$

1. Rovira, Pere: Poética y poesía, Madrid, 2016, p. 19. 